\title{
Parasites component community in wild population of Pterophyllum scalare Schultze, 1823 and Mesonauta acora Castelnau, 1855, cichlids from the Brazilian Amazon
}

\author{
By W. M. Farias Pantoja ${ }^{1}$, L. Vargas Flores ${ }^{1}$ and M. Tavares-Dias ${ }^{2}$ \\ ${ }^{1}$ Postgraduate Program on Amazon Region Continental Water Resources, Federal University of the western Pará (UFOPA) \\ Santarém, State of Pará, Brazil; ${ }^{2}$ Aquatic Organism Health Laboratory, Embrapa Amapá, Macapá, State of Amapá, Brazil
}

\section{Summary}

The aim of the present study was to compare the component parasite communities of the Pterophyllum scalare and Mesonauta acora cichlids in the Amazon River system in northern Brazil. From September to December 2012, 42 specimens of $P$. scalare and 38 specimens of $M$. acora were captured using hand nets and gillnets in the Igarapé Fortaleza basin, a tributary of the Amazon River in the state of Amapá. Of the P. scalare specimens examined, $97.6 \%$ were parasitized by Ichthyophthirius multifiliis, Tripartiella sp., Trichodina nobilis, Gussevia spiralocirra, Posthodiplostomum sp., Capillaria pterophylli, Ichthyouris sp. and Gorytocephalus spectabilis. Similarly, all specimens of $M$. acora were parasitized by I. multifiliis, Tripartiella sp, T. nobilis, Sciadicleithrum joanae, Posthodiplostomum sp., Pseudoproleptus sp., Ichthyouris sp. and G. spectabilis. However, for both hosts the dominance was of I. multifiliis and with an overdispersion of parasites. Parasite communities of $P$. scalare and $M$. acora were similar and only Pseudoproleptus sp. and Posthodiplostomum sp. were larvae. Brillouin diversity, parasite species richness and evenness were higher for $M$. acora than for P. scalare, which presented a negative correlation of parasite abundance with body size. Both cichlid species had parasite communities characterized by low diversity and low species richness, with a predominance of ectoparasite species and greatest richness of helminth species, with a low abundance of endoparasites. This was the first study on the parasite diversity in wild $P$. scalare and $M$. acora.

\section{Introduction}

In the Amazon basin, several Cichlidae species are of great importance to recreational fisheries, aquaculture and the aquarium trade. A large proportion of aquarium fish all over the world comes from the Amazon basin (Tavares-Dias et al., 2014), exported from Brazil, Colombia and Peru, and representing an important potential economic resource for the region (Gerstner et al., 2006).

Pterophyllum scalare Schultze, 1823 (Angelfish), is a cichlid that has a broad geographic distribution in South America, including Peru, Colombia, Guiana and Brazil (Cacho et al., 1999; Korzelecka-Orkisz et al., 2012; Froese and Pauly,
2015). This species inhabits areas of low water hardness that is slightly acidic. This cichlid is usually found near submersed wood and vegetation, which serve as shelter against predators (Korzelecka-Orkisz et al., 2012). In nature, this pelagic fish presents an omnivorous behavior, feeding mainly on insects, algae and smaller fish (Soares et al., 2011), as well as crustaceans (Froese and Pauly, 2015).

In South America, wild populations of $P$. scalare have been parasitized by Gussevia spiralocirra (Kritsky et al., 1986), Sciadicleithrum iphthimum (Kritsky et al., 1989), Icthyouris sp., Ichthyophthirius multifiliis Fouquet, 1876 and Gyrodactylus sp. (Tavares-Dias et al., 2010; Bittencourt et al., 2014). In the eastern Amazon region, P. scalare and M. acora occur mainly in floodplain areas of the Amazon River system and are usually captured near aquatic vegetation. However, there are no studies on the parasite community composition of these two cichlids in this ecosystem.

Mesonauta acora Castelnau, 1855 (acará-barbela), is a cichlid endemic to Brazil, occurring in the Amazon, Tocantins and Xingu river basins. This fish presents a benthopelagic behavior, inhabiting areas of up to $1 \mathrm{~m}$ in depth with a bottom substrate composed of sand and mud, and with the presence of aquatic plants. The diet of $M$. acora is composed of insects, aquatic invertebrates (Froese and Pauly, 2015) and algae, which makes this species of fish omnivorous.

Parasite communities in fish reflect interactions with the aquatic environment, as well as with their hosts and invertebrate communities in natural and artificial ecosystems. Since all these components may be involved in the life cycle of parasites, parasite assemblages may be environmental indicators, undergoing increases or decreases in their diversity, richness, abundance and prevalence as a function of a variety of environmental and non-environmental factors (Dogiel, 1961; Rakauskas and Blazevicius, 2009; Neves et al., 2013, 2015; Tavares-Dias et al., 2014;. Therefore, knowledge of parasites can aid in comprehending host-parasite relationships with the environment (Rakauskas and Blazevicius, 2009; TavaresDias et al., 2013, 2014; Neves et al., 2015), thus acting as an important tool for biodiversity evaluations.

Variations in parasite species richness among Cichlidae species provide a good model for studying diversification of 
communities among these hosts, as well as contributing towards knowledge of the biogeography of parasites of these Perciformes, which have a wide geographical distribution and endemic characteristics (Pérez-Ponce de León and Choudhury, 2005; Pariselle et al., 2011). In addition, whenever a wild Amazonian cichlid species is translocated to another region, there is always the possibility that its parasites will also be translocated with it (Bittencourt et al., 2014). The aim of the present study was thus to compare the component community of parasites in $P$. scalare and $M$. acora from Igarapé Fortaleza basin, a tributary of the Amazon River system in northern Brazil.

\section{Materials and methods}

\section{Area of study and fish collection procedures}

The Igarapé Fortaleza basin is located in the state of Amapá, eastern Amazon region (northern Brazil) and an important tributary to the Amazon River, which in turn is the main force forming the floodplain of this tributary influenced by the high rainfall levels of the Amazon region and the daily variations in the tides of the Amazon River (Takyama et al., 2004; Tavares-Dias et al., 2013). The floodplain is periodically covered by floodwaters rich in nutrients due to the rapid decomposition of grasses and animal remains or the humus layers of the forest, thus leading to high growth rates for the vegetation and invertebrate biomass (insects, zooplanktonic crustaceans and mollusks), which are then consumed by the fish (Gama and Halboth, 2004; Neves et al., 2015).

From September to December 2012, 42 specimens of P. scalare $(7.0 \pm 1.3 \mathrm{~cm}$ and $7.0 \pm 4.2 \mathrm{~g})$ and 38 specimens of $M$. acora $(6.7 \pm 1.2 \mathrm{~cm}$ and $6.7 \pm 4.7 \mathrm{~g})$ were caught in the same Igarapé Fortaleza basin $\left(00^{\circ} 02^{\prime} 37.5^{\prime \prime} \mathrm{N} ; 51^{\circ} 06^{\prime} 19.2^{\prime \prime}\right.$ W) locality in the Macapá municipality (State of Amapá, Brazil) for parasitological analysis. All fish were caught using hand nets and gillnets with mesh sizes of $10-25 \mathrm{~mm}$, and then transported live to the Health Laboratory of Aquatic Organisms from Embrapa Amapá, Macapá (AP).

In the Igarapé Fortaleza basin, the mean water temperature, dissolved oxygen level, $\mathrm{pH}$, electric conductivity, turbidity and total dissolved solids were determined using a multi-parameter sensor (model U-52, Horiba). Ammonia levels, alkalinity and hardness were measured using kits (ALFAKIT), while water transparency was measured using a Secchi disk.

\section{Sampling procedures and parasite analyses}

Fish were weighed $(\mathrm{g})$ and measured for length $(\mathrm{cm})$. The gills and gastrointestinal tract were then examined to ascertain whether any protozoan or metazoan parasites were present. All parasites collected were fixed, conserved, quantified and stained for identification using the methods recommended by Eiras et al. (2006). Ecological terms used were those recommended by Rohde et al. (1995) and Bush et al. (1997). Voucher specimens were deposited at the Scientific and Technological Research Institute of the State of Amapá
(IEPA), in the Scientific Collection Curation Office for the Fauna of Amapá (CCFA), under accession number IEPA 019-032-P.

The Brillouin index $(H B)$, parasite species richness, evenness $(E)$ and Berger-Parker dominance index $(d)$ were calculated for each infracommunity of parasites (Magurran, 2004), using the Diversity software (Pisces Conservation Ltd, UK). The dispersion index (DI) and discrepancy index $(D)$ were calculated using the Quantitative Parasitology 3.0 software, to detect the distribution pattern of parasite infracommunities (Rózsa et al., 2000) among species with prevalence $>10 \%$. Significance of the DI for each community was tested using the $d$ statistic (Ludwig and Reynolds, 1988).

To compare prevalence between $M$. acora and P. scalare, the chi-square test $\left(\chi^{2}\right)$ was used, followed by the Yates correction. The intensity, abundance, species richness, diversity $(H B)$, evenness $(E)$ and Berger-Parker dominance $(d)$ were compared between the two hosts using the Mann-Whitney test $(U)$. Spearman's correlation coefficient $\left(r_{\mathrm{s}}\right)$ was used to determine possible correlations of total length and body weight with the abundance of parasites, Brillouin index $(H B)$ and richness of the parasite species (Zar, 2010).

\section{Results}

Water quality was similar during collection of the fish (Table 1).

A total of 92421 parasites belonging to five taxa were collected from $P$. scalare: three Ciliophora species, one Monogenoidea, one Digenea, two Nematoda and one Acanthocephala. From M. acora, 73686 parasites were collected, which also belonged to five taxa: three Ciliophora, one Monogenoidea, two Nematoda, one Digenea and one Acanthocephala. In both hosts, the dominant species were the protozoa I. multifiliis (Ichthyophthiriidae), followed by Tripartiella sp. and Trichodina nobilis Chen, 1963 (Trichonidae). However, Sciadicleithrum joanae Kritsky, Thatcher \& Boeger, 1989; (Dactylogyridae) and Pseudoproleptus sp. (Cystidicolidae) were only found in M. acora, while Gussevia spiralocirra Kritsky, Thatcher \& Boeger, 1986; (Dactylogyridae) and

Table 1

Water parameters during capture of four cichlid species, Amazon River system, Brazil

\begin{tabular}{lcc}
\hline Parameters & $\begin{array}{l}\text { Pterophyllum } \\
\text { scalare }\end{array}$ & $\begin{array}{l}\text { Mesonauta } \\
\text { acora }\end{array}$ \\
\hline Water temperature $\left({ }^{\circ} \mathrm{C}\right)$ & $28.6 \pm 0.4$ & $28.8 \pm 0.4$ \\
Dissolved oxygen $\left(\mathrm{mg} \mathrm{L}^{-1}\right)$ & $2.1 \pm 0.4$ & $2.3 \pm 0.5$ \\
$\mathrm{pH}$ & $6.5 \pm 0.9$ & $6.3 \pm 0.6$ \\
Electric conductivity $\left(\mu \mathrm{s} \mathrm{cm}^{-1}\right)$ & $0.08 \pm 0.03$ & $0.06 \pm 0.02$ \\
Turbidity (NTU) & $60.3 \pm 5.2$ & $64.0 \pm 3.3$ \\
Total dissolved solids $\left(\mathrm{g} \mathrm{L}^{-1}\right)$ & $0.03 \pm 0.02$ & $0.03 \pm 0.02$ \\
Ammonia $\left(\mathrm{mg} \mathrm{L}^{-1}\right)$ & $0.50 \pm 0.4$ & $0.52 \pm 0.3$ \\
Alkalinity $\left(\mathrm{mg} \mathrm{L}^{-1}\right)$ & $30.0 \pm 0.1$ & $30.0 \pm 0.6$ \\
Hardness $\left(\mathrm{mg} \mathrm{L}^{-1}\right)$ & $30.0 \pm 0.2$ & $30.0 \pm 0.5$ \\
Water transparency $(\mathrm{cm})$ & $35.6 \pm 15.7$ & $28.5 \pm 12.7$ \\
\hline
\end{tabular}


Capillaria pterophylli Heinze, 1933 (Capillariidae) were found only in P. scalare. In addition, the greatest diversity was of helminth species, which include larvae (Table 2).

In the gills, the prevalence (Table 2) of I. multifiliis $\left(\chi^{2}=1.761, \mathrm{P}=0.184\right)$ was similar between $P$. scalare and $M$. acora, but the mean intensity $(U=385.0, \mathrm{P}=0.001)$ and mean abundance $(U=456.0, \mathrm{P}=0.0005)$ were greater for $P$. scalare. The prevalence $\left(\chi^{2}=4.091, \mathrm{P}=0.0431\right)$, mean intensity $(U=128.0, \quad \mathrm{P}=0.0001)$ and mean abundance $(U=335.0, \quad \mathrm{P}=0.0001)$ of Tripartiella sp. and T. nobilis were greater for $M$. acora. The prevalence $\left(\chi^{2}=57.844\right.$; $\mathrm{P}=0.0001)$ and mean abundance $(U=147.5, \mathrm{P}=0.0001)$ of Posthodiplostomum sp. were greater for $M$. acora.

In the intestine (Table 2), the prevalence $\left(\chi^{2}=7.026\right.$, $\mathrm{P}=0.008)$ and mean abundance $(U=544.0 ; \mathrm{P}=0.014)$ of Posthodiplostomum sp. were greater for $M$. acora, but the mean intensity $(U=98.0, \mathrm{P}=0.295)$ was similar for the two hosts. For Ichthyouris sp., the prevalence $\left(\chi^{2}=3.623\right.$, $\mathrm{P}=0.102)$ and mean abundance $(U=780.0, \mathrm{P}=0.862)$ were similar between $P$. scalare and M. acora, but the mean intensity $(U=318.5, \mathrm{P}=0.024)$ was greater for $P$. scalare. In $P$. scalare and $M$. acora, the prevalence $\left(\chi^{2}=0.334\right.$,
$\mathrm{P}=0.563)$ and mean abundance $(U=773.0, \mathrm{P}=0.809)$ of $G$. spectabilis were similar.

The parasites found in $P$. scalare and M. acora presented an aggregated dispersion (Table 3), which is a common pattern for freshwater fish.

The parasite diversity in $M$. acora was higher in $P$. scalare (Table 4). In $P$. scalare, there was a negative correlation between the Brillouin index and the length $\left(r_{\mathrm{s}}=-0.599\right.$, $\mathrm{P}=0.0001)$ and weight $\left(r_{\mathrm{s}}=-0.748, \mathrm{P}=0.0001\right)$ of the hosts, as well as between parasite species richness and length $\left(r_{\mathrm{s}}=-0.382, \mathrm{P}=0.012\right)$ and weight $\left(r_{\mathrm{s}}=-0.502\right.$, $\mathrm{P}=0.0007)$. However, for $M$. acora, no correlation was observed between the Brillouin index and the length $\left(r_{\mathrm{s}}=0.222, \mathrm{P}=0.157\right)$ or weight $\left(r_{\mathrm{s}}=0.144, \mathrm{P}=0.363\right)$ of the host, or between parasite species richness and length $\left(r_{\mathrm{s}}=-0.191, \mathrm{P}=0.225\right)$ and weight $\left(r_{\mathrm{s}}=0.147, \mathrm{P}=0.354\right)$. For Mesonauta acora, there was a predominance of hosts parasitized by 6-7 species of parasites, while for $P$. scalare there was a predominance of hosts parasitized by 5-6 parasite species (Fig. 1).

For P. scalare, the abundance of Tripartiella sp., T. nobilis, G. spiralocirra and C.pterophylli demonstrated a

Table 2

Parasitic indices in cichlids species, Amazon River system, Brazil.

\begin{tabular}{|c|c|c|c|c|c|c|c|c|}
\hline \multirow[b]{2}{*}{ Parasites } & \multicolumn{4}{|c|}{ Pterophyllum scalare $(\mathrm{n}=42)$} & \multicolumn{4}{|c|}{ Mesonauta acora $(\mathrm{n}=38)$} \\
\hline & $\mathrm{P}(\%)$ & $\mathrm{MI} \pm \mathrm{SD}$ & $\mathrm{MA} \pm \mathrm{SD}$ & SI & $\mathrm{P}(\%)$ & $\mathrm{MI} \pm \mathrm{SD}$ & $\mathrm{MA} \pm \mathrm{SD}$ & SI \\
\hline Ichthyophthirius multifiliis & 95.5 & $2187.7 \pm 1385.3$ & $2083.5 \pm 1431.0$ & Gills & 86.8 & $1.492 .0 \pm 1370.0$ & $1295.7 \pm 1372.5$ & Gills \\
\hline $\begin{array}{l}\text { Tripartiella sp. and } \\
\text { Trichodina nobilis }\end{array}$ & 64.3 & $94.4 \pm 90.0$ & $60.7 \pm 85.1$ & Gills & 84.2 & $499.7 \pm 443.6$ & $420.8 \pm 446.0$ & Gills \\
\hline Sciadicleithrum joanae & 0 & 0 & 0 & Gills & 89.4 & $8.7 \pm 6.5$ & $7.8 \pm 6.7$ & Gills \\
\hline Gussevia spiralocirra & 92.8 & $32.79 \pm 41.5$ & $30.4 \pm 40.9$ & Gills & 0 & 0 & 0 & - \\
\hline $\begin{array}{l}\text { Posthodiplostomum } \\
\text { sp. (metacercariae) }\end{array}$ & 4.8 & $38.5 \pm 47.3$ & $1.8 \pm 11.2$ & Gills & 89.4 & $4.0 \pm 3.7$ & $3.6 \pm 3.7$ & Gills \\
\hline $\begin{array}{l}\text { Posthodiplostomum } \\
\text { sp. (metacercariae) }\end{array}$ & 26.2 & $33.55 \pm 43.3$ & $8.8 \pm 26.2$ & Intestine & 55.3 & $365.3 \pm 622.7$ & $201.9 \pm 393.5$ & Intestine \\
\hline Capillaria pterophylli & 28.6 & $3.5 \pm 3.8$ & $1.0 \pm 2.6$ & Intestine & 0 & 0 & 0 & - \\
\hline Pseudoproleptus sp. (larvae) & 0 & 0 & 0 & - & 7.9 & $1.0 \pm 0$ & $0.1 \pm 0.3$ & Intestine \\
\hline Ichthyouris sp. & 69.0 & $20.5 \pm 20.8$ & $14.1 \pm 19.7$ & Intestine & 86.8 & $10.5 \pm 10.6$ & $9.2 \pm 10.5$ & Intestine \\
\hline Gorytocephalus spectabilis & 4.8 & $1.0 \pm 0$ & $0.04 \pm 0.2$ & Intestine & 7.9 & $1.0 \pm 0$ & $0.1 \pm 0.3$ & Intestine \\
\hline
\end{tabular}

P, Prevalence; MI, Mean intensity; SD, Standard deviation; MA, Mean abundance; SI, Site of infection.

Table 3

Dispersion index (DI), $d$-statistic, discrepancy index (D) and frequency of dominance (FD) for infracommunities of parasites in species of cichlids, Amazon River system, Brazil

\begin{tabular}{|c|c|c|c|c|c|c|c|c|}
\hline \multirow{2}{*}{$\begin{array}{l}\text { Hosts } \\
\text { Parasites }\end{array}$} & \multicolumn{4}{|c|}{ Pterophyllum scalare $(\mathrm{n}=42)$} & \multicolumn{4}{|c|}{ Mesonauta acora $(\mathrm{n}=38)$} \\
\hline & DI & $d$ & $\mathrm{D}$ & FD $(\%)$ & DI & $d$ & $\mathrm{D}$ & FD $(\%$ \\
\hline $\begin{array}{l}\text { Tripartiella sp. and } \\
\text { Trichodina nobilis }\end{array}$ & 4.488 & 10.18 & 0.544 & 0.028 & 3.162 & 6.79 & 0.402 & 0.217 \\
\hline Ichthyophthirius multifiliis & 2.266 & 4.63 & 0.274 & 0.947 & 2.849 & 6.01 & 0.357 & 0.668 \\
\hline Sciadicleithrum joanae & - & - & - & - & 5.456 & 11.59 & 0.655 & 0.004 \\
\hline Gussevia spiralocirra & 4.322 & 9.82 & 0.811 & 0.014 & - & - & - & - \\
\hline $\begin{array}{l}\text { Posthodiplostomum } \\
\text { sp. (gills) }\end{array}$ & - & - & - & - & 2.579 & 5.31 & 0.452 & 0.002 \\
\hline $\begin{array}{l}\text { Posthodiplostomum } \\
\text { sp. (intestine) }\end{array}$ & 2.853 & 6.29 & 0.353 & 0.001 & 1.757 & 2.90 & 0.377 & 0.104 \\
\hline Capillaria pterophyllum & 3.013 & 6.71 & 0.791 & 0.0005 & - & - & - & - \\
\hline Ichthyouris sp. & 3.295 & 7.43 & 0.544 & 0.006 & 2.737 & 5.73 & 0.447 & 0.005 \\
\hline
\end{tabular}


Table 4

Mean diversity indexes \pm standard deviation and ranges (in parentheses) for species of cichlids, Amazon River system, Brazil. $U$ : Mann-Whitney test

\begin{tabular}{lccc}
\hline Indexes & Pterophyllum scalare $(\mathrm{n}=42)$ & Mesonauta acora $(\mathrm{n}=38)$ & $\mathrm{P}$ \\
\hline Brillouin & $0.26 \pm 0.23(0.009-1.15)$ & $0.62 \pm 0.21(0.15-1.07)$ & 197.0 \\
Species richness & $3.7 \pm 1.2(1-8)$ & $5.0 \pm 1.3(1-6)$ & 374.5 \\
Evenness & $0.12 \pm 0.10(0.004-0.54)$ & $0.32 \pm 0.11(0.07-0.54)$ & 0.0001 \\
Berger-Parker & $0.90 \pm 0.16(0.81-1.00)$ & $0.72 \pm 0.13(0.48-0.97)$ & 0.0001 \\
\hline
\end{tabular}

negative correlation with the length and weight of the hosts. However, for M. acora, no correlation was found between the abundance of parasites and the length and weight of the hosts (Table 5).

\section{Discussion}

A narrow 3-month time window was used in this first study on parasite diversity in wild $P$. scalare and $M$. acora. Hence, the similar parasite community of these hosts can present a tendency to maintain synchronization with the Amazonian hydrological events, such as the rainy and dry seasons. In addition, for P. scalare, the abundance of Tripartiella sp.,

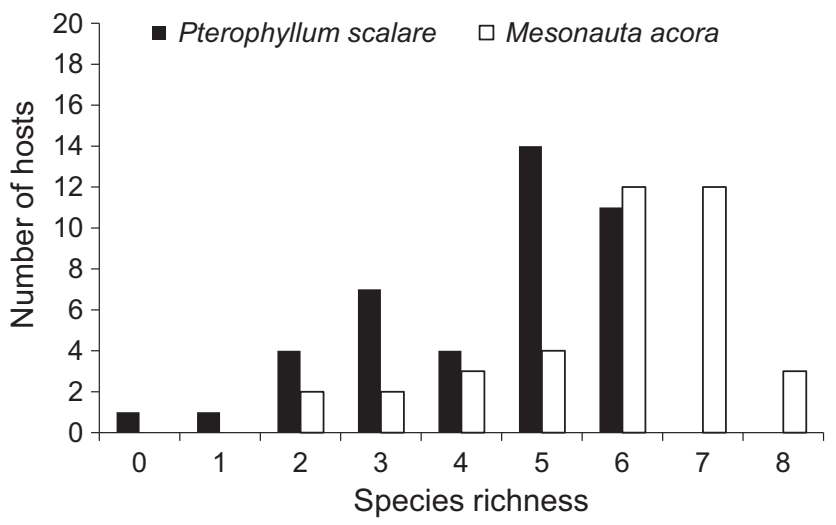

Fig. 1. Parasite species richness in Pterophyllum scalare $(\mathrm{n}=42)$ and Mesonauta acora $(\mathrm{n}=38)$ from the Amazon River system (Brazil).
T. nobilis, G. spiralocirra and C. pterophylli, Brillouin index and parasite species richness presented a negative correlation with the size of the hosts, indicating that size was a strong determining factor for abundance, diversity and richness of the parasites. However, for $M$. acora, the size of the hosts did not influence the parasite abundance or diversity parameters. Mesonauta acora and P. scalare presented overdispersion of ectoparasites and endoparasites. This same dispersion pattern has also been reported for other hosts from the Amazon River system (Tavares-Dias et al., 2013, 2014; Neves et al., 2015).

For P. scalare and M. acora there was dominance of Tripartiella sp., T. nobilis and I. multifiliis, all of which are ciliate species that can parasitize wild fish without necessarily causing apparent damage to the hosts (Basson and Van As, 2002; Bittencourt et al., 2014; Tavares-Dias et al., 2014) when the infection levels are low. Low infection levels of Tripartiella sp. were observed in $P$. scalare and $M$. acora, although the $P$. scalare were more parasitized. Mesonauta acora and $P$. scalare had a similar prevalence of $I$. multifiliis, while the mean intensity and abundance were greater for $P$. scalare host fish, which showed greater susceptibility toward this ciliate. Therefore, Trichodina nobilis, a trichodinid of carp species and Nile tilapia was introduced in the basin here. Biological invasions occur at alarming rates worldwide, being widely recognized as threats to the integrity and functioning of natural ecosystems in a variety of countries (Poulin et al., 2011; Bittencourt et al., 2014).

Gussevia spiralocirra was found only in P. scalare, while $S$. joanae occurred only in $M$. acora; both hosts had a high prevalence of these monogenoideans but were low intensity

Table 5

Spearman's correlation coefficient $\left(r_{\mathrm{s}}\right)$ for parasite abundance in relation to total length $(\mathrm{cm})$ and body mass $(\mathrm{g})$ of cichlid species, Amazon River system, Brazil

\begin{tabular}{|c|c|c|c|c|c|c|c|c|}
\hline \multirow{3}{*}{$\begin{array}{l}\text { Hosts } \\
\text { Parasites }\end{array}$} & \multicolumn{4}{|c|}{ Pterophyllum scalare } & \multicolumn{4}{|c|}{ Mesonauta acora } \\
\hline & \multicolumn{2}{|c|}{ Body length } & \multicolumn{2}{|c|}{ Body weight } & \multicolumn{2}{|c|}{ Body length } & \multicolumn{2}{|c|}{ Body weight } \\
\hline & $r_{\mathrm{s}}$ & $\mathrm{P}$ & $r_{\mathrm{s}}$ & $\mathrm{P}$ & $r_{\mathrm{s}}$ & $\mathrm{P}$ & $r_{\mathrm{s}}$ & $\mathrm{P}$ \\
\hline Ichthyophthirius multifiliis & 0.1678 & 0.2882 & 0.1765 & 0.2633 & 0.2857 & 0.0820 & 0.3094 & 0.0587 \\
\hline Tripartiella sp. and Trichodina nobilis & -0.4046 & 0.0078 & -0.4614 & 0.0021 & 0.2898 & 0.0775 & 0.2608 & 0.1137 \\
\hline Sciadicleithrum joanae & - & - & - & - & -0.0331 & 0.8435 & -0.0708 & 0.6726 \\
\hline Gussevia spiralocirra & -0.5298 & 0.0003 & -0.5863 & 0.0001 & - & - & - & - \\
\hline Posthodiplostomum sp. (gills) & 0.1444 & 0.3615 & 0.1788 & 0.2572 & 0.0853 & 0.6107 & 0.0149 & 0.9294 \\
\hline Posthodiplostomum sp. (intestine) & -0.1722 & 0.2755 & -0.3330 & 0.0311 & 0.1893 & 0.2550 & 0.1539 & 0.3563 \\
\hline Capillaria pterophyllum & -0.4336 & 0.0041 & -0.4140 & 0.0064 & - & - & - & - \\
\hline Pseudoproleptus sp. & - & - & - & - & 0.0625 & 0.7092 & 0.0327 & 0.8455 \\
\hline Ichthyouris sp. & 0.1472 & 0.3523 & 0.0100 & 0.9498 & -0.0097 & 0.9537 & 0.0188 & 0.9109 \\
\hline
\end{tabular}


and abundance. This high prevalence of monogenoideans is due to the direct monogenoidean cycle, which is facilitated by the lentic and eutrophisized environment in the Igarapé Fortaleza basin, which suffers from a high influence of urbanization (Tavares-Dias et al., 2014; Neves et al., 2015).

In $P$. scalare, the infection levels by $C$. pterophylli were low, as well as the infection levels by Pseudoproleptus larvae in M. acora, which is a paratenic host for this nematode. However, Ichthyouris sp., the nematode with the highest infection levels in P. scalare and $M$. acora, presented similar prevalence and abundance in these hosts, although there was greater intensity in P. scalare. Pseudoproleptus sp. and Ichthyouris sp. have also been reported as parasitizing other species of Cichlidae from same region as this study (Bittencourt et al., 2014). However, both nematode species present a complex life cycle (Moravec and Laoprasert, 2008), which is still unknown.

Metacercariae of Posthodiplostomum sp. were found in the gills and intestines of $P$. scalare and M. acora. However, a greater number of infections occurred in $M$. acora, due to its greater contact with the infecting forms of Posthodiplostomum sp. In $P$. scalare and $M$. acora, the high prevalence and intensity of metacercariae of Posthodiplostomum sp. indicate that the abundance of mollusks (the first intermediate host) and the presence of piscivorous birds (probable definitive hosts) are the causes of these infections in fish, which are the secondary intermediate hosts of these digeneans (Ritossa et al., 2013; Neves et al., 2015). These, results corroborate that host behavior is of great importance in the level of infection by this species of digeneans that is common in fish species from the eastern Amazon (Neves et al., 2013, 2015; Bittencourt et al., 2014; Tavares-Dias et al., 2014).

A similar and low parasitism was observed in $P$. scalare and $M$. acora by $G$. spectabilis, indicating that these fish are paratenic hosts of this acanthocephalan. This acanthocephalan has also been reported as parasitizing other cichlid species from eastern Amazon (Bittencourt et al., 2014; Tavares-Dias et al., 2014), thus indicating that this Neotropical acanthocephalan has a low parasitic specificity. Acanthocephalan have a complex life cycle that requires one or more intermediate hosts (usually an arthropod or mollusk), one paratenic host, as well as a definitive host where the parasites reproduce sexually (Schmidt, 1985; Médoc et al., 2011).

In summary, the main factors responsible for structuring the parasite community in $P$. scalare and $M$. acora were principally the behavior of these hosts and the availability of endoparasite infections in the environment, although for $P$. scalare the size of this host was also an important factor. Furthermore, the results indicate that procedures of quarantine and prophylaxis to avoid risks of parasite transfers must be enforced, because the exportation of wild ornamental fish has been responsible for the introduction of parasites to other continents where such procedures are usually not performed.

\section{Acknowledgements}

This study was developed in accordance with the principals upheld by the Brazilian College of Animal Experimentation
(COBEA). The authors are grateful to the National Council for Research and Technological Development (CNPq), for the research bursary granted to M. Tavares-Dias.

\section{References}

Basson, L.; Van As, J. G., 2002: Trichodinid ectoparasites (Ciliophora: Peritrichia) of freshwater fishes of the family Anabantidae from the Okavango River and Delta (Botswana). Folia Parasitol. 49, 169-181.

Bittencourt, L. S.; Pinheiro, D. A.; Cárdenas, M. Q.; Fernandes, B. M. M.; Tavares-Dias, M., 2014: Parasites of native Cichlidae populations and invasive Oreochromis niloticus (Linnaeus, 1758) in tributary of Amazonas River (Brazil). Braz. J. Vet. Parasitol. 23, 44-54.

Bush, A. O.; Lafferty, K. D.; Lotz, J. M.; Shostak, W., 1997: Parasitology meets ecology on its own terms: Margolis et al., Revisited. J. Parasitol. 83, 575-583.

Cacho, M. S. R. F.; Yamamoto, M. E.; Chellappa, S., 1999: Comportamento reprodutivo do acará bandeira, Pterophylum scalare Cuvier \& Valenciennes (Osteichthyes, Cichlidae). Rev. Brasil. Zool. 16, 653-664.

Dogiel, V. A., 1961: Ecology of the parasites of freshwater fishes. In: Parasitology of fishes; V. A. Dogiel, G. K. Petrushevsky and Y. I. Polyanski (Eds.) University Press, Leningrad, pp. 1-47.

Eiras, J. C.; Takemoto, R. M.; Pavanelli, G. C., 2006: Métodos de estudo e técnicas laboratoriais em parasitologia de peixes. Ed. Eduem, Maringá, pp.1-199.

Froese, R.; Pauly, D., (Eds.) 2015: FishBase World Wide Web electronic publication. Available at: www.fishbase.org, version (accessed 10 February 2015).

Gama, C. S. Halboth, D. A., 2004: Ictiofauna das ressacas das bacias do Igarapé da Fortaleza e do Rio Curiaú. In: Diagnóstico das ressacas do estado do Amapá: bacias do Igarapé da Fortaleza e Rio Curiaú, Macapá-AP. L. R. Takiyama, A. Q. Silva (orgs.). CPAQ/IEPA e DGEO/SEMA, Macapá, pp. 23-52.

Gerstner, C. L.; Ortega, H.; Sanchez, H.; Graham, D. L., 2006: Effects of the freshwater aquarium trade on wild fish populations in differentially-fished areas of the Peruvian Amazon. J. Fish Biol. 68, 862-875.

Korzelecka-Orkisz, A.; Szalast, Z.; Pawlos, D.; Smaruj, I.; Tañski, A.; Szulc, J.; Formicki, K., 2012: Early ontogenesis of the angelfish, Pterophyllum scalare Schultze, 1823 (Cichlidae). Neotrop. Ichthyol. 10, 567-576.

Kritsky, D. C.; Thatcher, V. E.; Boeger, W. A., 1986: Neotropical Monogenea. 8. Revision of Urocleidoides (Dactylogyridae, Ancyrocephalinae). Proc. Helminth. Soc. Wash. 53, 1-37.

Kritsky, D. C.; Thatcher, V. E.; Boeger, W. A., 1989: Neotropical Monogenoidea 15. Dactylogyrids from the gills of Brazilian Cichlidae with proposal of Sciadicleithrum gen. n. (Dactylogyridae). Proc. Helminth. Soc. Wash. 56, 128-140.

Ludwig, J. A.; Reynolds, J. F., 1988: Statistical ecology: a primer on methods and computing. Wiley-Interscience Publications, New York. pp. 1-337.

Magurran, A. E., 2004: Measuring biological diversity. Blackwell Science, Oxford. pp. 1-25.

Médoc, V.; Rigaud, T.; Motreuil, S.; Perrot-Minnot, M. J.; Bollache, L., 2011: Paratenic hosts as regular transmission route in the acanthocephalan Pomphorhynchus laevis: potential implications for food webs. Naturwissenschaften 98, 825-835.

Moravec, F.; Laoprasert, T., 2008: Redescription of Ichthyouris bursata Moravec \& Prouza, 1995 (Nematoda: Pharyngodonidae), a parasite of wild and aquarium-reared discus Symphysodon spp. (Osteichthyes). Syst. Parasitol. 71, 137-143.

Neves, L. R.; Pereira, F. B.; Tavares-Dias, M.; Luque, J. L., 2013: Seasonal influence on the parasite fauna of a wild population of Astronotus ocellatus (Perciformes: Cichlidae) from the Brazilian Amazon. J. Parasitol. 99, 718-721.

Neves, L. R.; Braga, E. C. R.; Tavares-Dias, M., 2015: Diversity of parasites in Curimata incompta (Curimatidae), a host from Ama- 
zon River system in Brazil. J. Parasitic Dis. 1-15. doi:10.1007/ s12639-015-0674-0.

Pariselle, A.; Boeger, W. A.; Snoeks, J.; Billon Bilong, C. F.; Morand, S.; Vanhove, M. P. M., 2011: The monogenean parasite fauna of cichlids: a potential tool for host biogeography. Int. J. Evol. Biol 2011, Article ID 471480. doi:10.4061/2011/471480.

Pérez-Ponce de León, G.; Choudhury, A., 2005: Biogeography of helminth parasites of freshwater fishes in Mexico: the search for patterns and processes. J. Biogeogr. 32, 645-659.

Poulin, R.; Paterson, R. A.; Townsend, C. R.; Tompkins, D. M.; Kelly, W., 2011: Biological invasions and the dynamics of endemic diseases in freshwater ecosystems. Freshw. Biol. 56, 676688 .

Rakauskas, V.; Blazevicius, C., 2009: Distribution, prevalence and intensity of roach (Rutilus rutilus (Linnaeus, 1758)) parasites in inland waters of Lithuania in 2005-2008. Acta Zool. Lit. 19, 99108 .

Ritossa, L.; Flores, V.; Viozzi, G., 2013: Life-cycle stages of a Posthodiplostomum species (Digenea: Diplostomidae) from Patagonia, Argentina. J. Parasitol. 99, 777-780.

Rohde, K.; Hayward, C.; Heap, M., 1995: Aspects of the ecology of metazoan ectoparasites of marine fishes. Int. J. Parasitol. 25, 945-970.

Rózsa, L.; Reiczigel, J.; Majoros, G., 2000: Quantifying parasites in samples of hosts. J. Parasitol. 86, 228-232

Schmidt, G. D., 1985: Development and life cycles. In: Biology of the Acanthocephala. In: D. W. T. Crompton, B. B. Nickol (eds.). Cambridge University Press, Cambridge. p. 273-286.
Soares, M. G. M.; Costa, E. L.; Siqueira Souza, F. K.; Anjos, H. D. B.; Yamamoto, K. C.; Freitas, C. E. C., 2011: Peixes de lagos do médio Rio Solimões. 2a ed. Reggo Editora, Manaus, pp. 1-175.

Takyama, L. R.; Silva, A. Q.; Costa, W. J. P., Nascimento, H. S 2004: Qualidade das águas das ressacas das bacias do Igarapé da Fortaleza e do rio Curiaú. In: L. R. Takyama, A. Q. Silva (Org.). Diagnóstico de ressacas do Estado do Amapá: bacias do Igarapé da Fortaleza e do Curiaú, Macapá, AP. CPAQ/IEPA e DGEO/SEMA, Macapá. pp. 81-104.

Tavares-Dias, M.; Lemos, J. R. G.; Martins, M. L., 2010: Parasitic fauna of eight species of ornamental freshwater fish species from the middle Negro River in the Brazilian Amazon region. Rev. Brasil. Parasitol. Vet. 19, 29-33.

Tavares-Dias, M.; Neves, L. R.; Pinheiro, D. A.; Oliveira, M. S. B. Marinho, R. G. B., 2013: Parasites in Curimata cyprinoides (Characiformes: Curimatidae) from eastern Amazon. Brazil. Acta Sci. Biol. Sci. 35, 595-601.

Tavares-Dias, M.; Oliveira, M. S. B.; Gonçalves, R. A.; Silva, L. M., 2014: Ecology and seasonal variation of parasites in wild $A e$ quidens tetramerus, a Cichlidae from the Amazon. Acta Parasitol. 59, 158-164.

Zar, J. H., 2010: Biostatistical analysis, 5th edn. Prentice Hall, Upper Saddle River, NJ. pp. 1-944.

Author's address: Marcos Tavares-Dias, Embrapa Amapá, Rodovia Juscelino Kubitschek, km 5, No 2600, 68903-419, Macapá, AP, Brazil.

E-mail: marcos.tavares@embrapa.br 